\title{
Reproductive features in the female raccoon dog (Nyctereutes procyonoides)
}

\author{
Maija H. Valtonen, E. J. Rajakoski and J. I. Mäkelä \\ Department of Veterinary Medicine, University of Helsinki, 00710 Helsinki 71, and \\ Helve Research Farm, 02880 Veikkola, Finland
}

The raccoon dog has only recently been farmed, for its fur, in Finland from stock originating by capture of wild animals. Knowledge of the reproduction of the raccoon dog is limited (Asdell, 1964) and its breeding still involves several problems. Since the raccoon dog is a member of the family Canidae, its mating features can be expected to resemble those of the dog and fox whose reproductive physiology is fairly well known (Harrop, 1960; Venge, 1959). However, more information about the oestrous cycle and gestation in the raccoon dog is needed for adapting this naturally monogamous species to the polygamous mating used in the fur industry.

In this study which lasted three seasons, starting in 1974, 20 female raccoon dogs were used in the first two seasons and 14 in the third. All the animals were housed at Helve's Research Farm, Veikkola. During the breeding seasons the animals were inspected daily and a closer examination of the genitalia was made three times a week when taking the vaginal smears. The Giemsa-stained smears were evaluated by estimating the relative amounts of different cell types encountered in the smear, i.e. parabasal, intermediate, superficial and anuclear cells (Bell, Bailey \& Christie, 1973).

The mating seasons of the raccoon dogs investigated were in February and March, the mean date for mating being on 16 March in 1974, on 9 March in 1975 and 22 February in 1976.

The anatomy of the sexual organs of a female raccoon dog are typically canid, varying in size with the age and season. In our study, pro-oestrus was marked by gradual swelling of the vulva and a mucopurulent discharge which was sometimes quite abundant. The swelling continued until oestrus and the vulval lips were often separated. The mean duration of pro-oestrus, characterized by vulval swelling and discharge, was $7 \cdot 6 \pm 3 \cdot 5$ days (S.D.), ranging from 2 days to 2 weeks. Oestrus, the period when the female was willing to mate, lasted for $3 \cdot 9 \pm 1 \cdot 2$ days. Polygamous mating was attempted when the signs of oestrus were strongest by placing the male in the female's box for 1 or more days.

In captivity the raccoon dog turned out to be a 'shy breeder', mating taking place during the night or early in the morning. As the animals adapted to captive conditions, the signs of oestrus became more pronounced and coitus was sometimes observed. The copulation of raccoon dogs resembles that of dogs and foxes. The duration of mating averages about $6 \mathrm{~min}$, ranging from 2 to $10 \mathrm{~min}$. After dismounting, the male stands by the side of the female. During the passive phase, when the animals are locked together, they often lie with their abdomens towards each other.

The gestation period was $61 \cdot 0 \pm 2 \cdot 0$ days, ranging from 59 to 64 days, in 9 animals. The mean litter size was $5 \cdot 0 \pm 2 \cdot 3$. The results of our study confirm the earlier reports for the raccoon dog (Schmidt, 1931, 1937; Schneider, 1950), of the time of the breeding season and the gestation period. The smaller litter size in our study, compared with that of 6.3 reported by Schneider (1950) and 7.5 by Schmidt (1937), is probably related to the short time that raccoon dogs have been farmed in Finland, because in natural conditions they may have litters with up to 19 young (Geptner \& Naumov, 1967).

During anoestrus the vaginal smear consisted of mostly parabasal and a few intermediate cells with moderate numbers of leucocytes and amount of mucus. In pro-oestrus the mucopurulent vaginal discharge was characterized by the abundance of leucocytes and some debris in the smear; some increase in the proportion of superficial cells was also seen (Pl. 1, Fig. 1). In oestrus the number of leucocytes regularly found in the vaginal smear of the raccoon dog decreased, but did not disappear (PI. 1, Fig. 2), and in metoestrus there was again a marked increase (Pl. 1, Fig. 3). Cornification of the 
epithelial cells during oestrus was less obvious than reported for the dog and fox and the proportion of parabasal and intermediate cells to the number of superficial and anuclear cells was about one to three. No red blood cells were seen in the smears of the raccoon dog during the oestrous cycle and the discharge was mucopurulent throughout pro-oestrus and oestrus. In dogs and foxes the reappearance of leucocytes in the smear coincides with ovulation and the beginning of progesterone secretion from the corpus luteum (Johansson, 1941 ; Sokolowski, 1973), but the presence of leucocytes in the vaginal smear of raccoon dogs throughout the whole oestrous cycle prevents this characteristic from being used as a criterion for ovulation in this species.

Although the main characteristics of the reproductive pattern of the raccoon dog were very similar to those seen in other canid species, the differences in vaginal cytology demand further study when more adapted animals are available.

This work was supported by a grant from the Yrjö Helve Foundation.

\section{References}

ASDELL, S.A. (1964) Nyctereutes procyonoides Gray. In Patterns of Mammalian Reproduction, p. 441. Cornell University Press, Ithaca, New York.

Bell, E.T., BaIley, J.B. \& Christie, D.W. (1973) Studies on vaginal cytology during the canine oestrous cycle. Res. vet. Sci. 14, 173-179.

Geptner, V.G. \& Naumov, N.P. (1967) Mlekopitajustšije Sovjetskovo Sojuza, pp. 66-96. Vysłaja škola, Moscow.

HARROP, A.E. (1960) Reproduction in the Dog. Baillière, Tindall \& Cox, London.

Johansson, I. (1941) Oestrus and mating in the silver fox. Lantbr. Högskol. Ann. Uppsala 9, 239-263.
ScHMIDT, F. (1931) Erfahrungen und Beobachtungen bei Zuchtversuchen mit dem Marderhund. Deutsche Pelztiersucht. 4, 87-90.

SchmidT, F. (1937) Über die Zucht des Marderhundes. Deutsche Pelztierzucht. 12, 235-237.

SCHNEIDER, K.M. (1950) Zur gewichtsmässigen Jugendentwicklung gefangen gehaltener Wiltcaniden nebst einigen zeitlichen Bestimmungen über ihre Fortpflanzung. Zool. Anz., Suppl. 15, 271-285.

Sokolowski, J.H. (1973) Reproductive features and patterns in the bitch. J. Am. Anim. Hosp. Ass. 9, $71-81$.

VENGE, O. (1959) Reproduction in the fox and mink. Anim. Breed. Abstr. 27, 129-145.

Received 28 Jume 1977 


\section{PLATE 1}
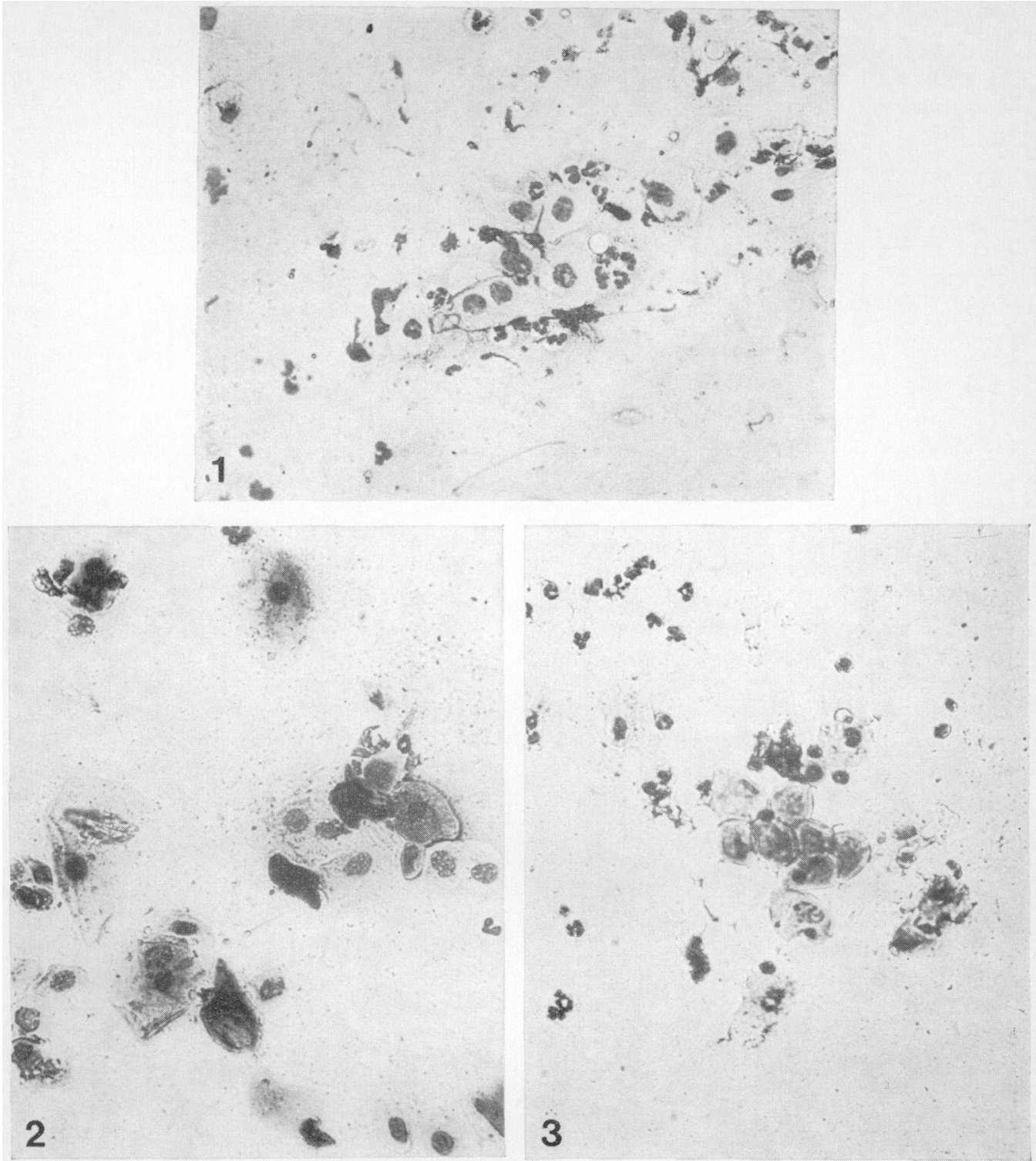

Fig. 1. Vaginal smear of a raccoon dog in pro-oestrus, showing parabasal and intermediate cells as well as leucocytes.

Fig. 2. Vaginal smear of raccoon dog in oestrus. Anuclear, superficial, intermediate and parabasal cells are present as well as leucocytes and spermatozoa.

Fig. 3. Vaginal smear of a raccoon dog in early metoestrus, characterized by parabasal and intermediate cells, a few superficial cells and increasing numbers of leucocytes. 